dyspnca, the purple lividity of the face, the convulsion, the convulsive fall, the coma, and the delirium, belong to the latter. The milder form occurs without laryngismus. Tracheotomy can, therefore, have no application in such a case. The graver form, on the contrary, essentially depends upon laryngismus, and is incompatible with a just and ample opening into the trachea.

"The same remark applies to every form of real, general, and complete convulsion - epileptic, puerperal, infantile. Being dependent on laryngismus, such convulsion cannot occur if tracheotomy be efficiently performed.

"We have to consider whether the effects of such convulsion-and they are surely dire enough-justify the heroic remedy.

"There is also another question. In what degree can the operation be simplified and improved?

"I am of opinion that a much lighter and more commodious tube may be used; and I think that where a protracted opening is required, its edges may be perfectly healed, leaving a permanent opening, which may be closed by removing those edges when this is thought to be desirable. The orifice ought, too, to be protected from the influence of the cold atmosphere by a cage of wire, and covered by cotton net.

"I should add, that I regard Mr. Anderson's modification of miy trachéotome as a very great improvement."

In thus adducing a second instance of the effectual prevention of epileptic convulsion by tracheotomy, I cannot but congratulate myself on the discovery of the means of preventing so Herculean a form of disease by any remedy, however heroic. If that remedy be formidable, the malady is formidable in a tenfold degree. If tracheotomy wears a fearful aspect, convulsion, coma, mania, paralysis, idiocy,-the effects of the epilepsia gravior,--wear an aspect still more fearful.

In a future communication I purpose to lay before the profession a disquisition on the following statements, to which observation and theory have alike led me:-

1. The first is, that the apoplexia mitior and the epilepsia mitior alike imply and depend on trachelismus.

2. The second, that the apoplexia gravior and the epilepsia gravior alike imply and depend on laryngismus.

3. The third, that phlebotomy bears a relation to trachelismus somewhat similar to that which tracheotomy does to laryngismus.

These propositions I commend to your readers' attention until I am enabled to enter more fully into their discussion.

Before I conclude, I beg to be permitted to correct an error in my paper of last week. It occurs at page 526, col. 2 , line 7 . Instead of "These were cases of apoplectic laryngismus," it ought to be, "Of these cases, the first is an instance of apoplectic laryngismus, the second of spasmodic laryngismus." The latter would obviously soon have become puerperal consulsion, had its course not been arrested.

I am, Sir, your obedient servant,

38, Grosvenor-street, Dec. 5th, 1851 . Marshall Hali.

\section{THE SPINAI INSTITUTION}

\section{To the Editor of THE LANCET.}

Sin,-With every intention of your reviewer-and I may say, of reviewers generally - to mutilate, to maim, to cut to pieces, the work of a young author, no matter how ample the sources from which he may have obtained his information, or how hard and protracted the study and investigation that inspired him with the confidence to commit his ideas and opinions to paper, I must say that it was with the utmost pleasure and satisfaction that I perceived in The LAANCET of Nov. 8 th, how utterly he had failed to inflict upon me all the injury he could desire or command, or to call down upon me the odium of my professional brethren.

Why, is it credible, that out of a notice of my work on the "Spine," etc., extending over a space of four columns and upwards, but barely two columns have been allotted to the dis cussion of the real merits of the book itself? the other matter consisting of collateral subjects connected with the life and practice of my late father, and not directly bearing upon myself. It is, however, with this collateral natter that I have presently to deal, since in it are involved statements that demand from me an anqualified contradiction.

It is not a little to be proud of, that from 234 closely printed pages, of which my work consists, upon every one of which your critic has attempted to convict me of at least gross inconsistency, if not of positive prevarication, he has, to his chagrin, only been able to do so in one or two trivial instances; and even there I think that I could show that a more perfect knowledge of the subject upon which he has essayed to form a judgment, would equally have destined him to signal failure. Knowing, then, as well $I$ do, his wish and determination to say nothing good or landatory of either myself or my production, I repeat that it is in the highest degree flattering to see how utterly he has failed in his attempts to call down ridicule upon the opinions advanced and practice adrocated in the pages of "the Spine, its Curvatures, and other Diseases."

My object in requesting the favour of having this letter inserted in 'THE LANCET, however, is not to complain of the manner in which I, personally, have been dealt with, but for the purpose of vindicating the truth of certain statements which I made in my work, and to the correctness of which I feel so strictly pledged, that I feel I should be wanting in my duty to myself, to my late father, and to the medical profession, provided I were to let them pass by unnoticed, since your reviewer has not scrupled to say that my statements of these particulars are false and erroneous.

To commence, then, with the primary part of the review, in which I am traduced for having asserted that my father was the founder of the Hospital for the Cure of Deformities, to which I am now one of the surgeons. I have to ask your reviewer what it is in his opinion that should constitute a "founder." Is it not something like the following that entitles a man to such an honourable distinction, provided that what he has founded be an honourable thing? -

We will suppose a gentleman-and he shall be a medical gentleman, too-who, in addition to being far from wealthy, has a numerous family, and is of a most philanthropic disposition, ever seeking to benefit others at the expense of his own time, his own comfort, his own health, and the welfare of his children. Well, this gentleman discovers something-no matter whatwhich he believes to be most potent in alleviating the bitter agons of his fellow-beings who are the victims of some bodily and hitherto almost irremediable disease; and so impressed is he with the truth of his belief, and so zealous in putting its merits to the test, that he penetrates into the most squalid haunts of this great city, in search of objects who, from the severity of their complaints, had retired from the notice of the public eye into some lone and miserable dwelling, to linger out a life of sorrow and suffering. Day and night - for we will suppose him almost supernaturally energetic-he pursues this arduous course, never knowing fatigue or tiring of his task, or thinking how many more profitable-in a worldly point of view-engagements were awaiting his being able to fulfil them. At the lapse of some time, success begins to attend upon the efforts of the philanthropist, but poverty, the want of food, the wretched habitations of the poor, are all against the perfect success of his exertions, and he finds that something else is wanting to promote the entire well-doing of his plans, - he finds, in fact, that to cure a disease whose very existence has originated in and is fostered by weakness and debility, it is necessary to withdraw the poor sufferers from the baneful influences of their miserable and squalid homes, whose privation and want are hurrying them to the grave, so that a better chance of recovery may be afforded them. What, then, is to be done? They can be attended at their own homes; but this is not enough, and, alas! there is no refuge or asylum that will open its doors to receive them. How, then, are they to be rescued? Why, it so happens that the ideal being of whom we are speaking possesses a large house, in which are many airy and light apartments, and in the fulness of his philanthropic spirit he forgets every discomfort that must attend upon so rash a course, and determines upon allotting in his ow abode a certain number of rooms for the purpose of receiving the dying sufferers, who else would have sunk to rest unheard of and unpitied. The rooms, before so gay and comfortable, are speedily stripped of their ordinary adornments; and behold, in the very centre of his own home an hospital is established, where, day by day, and oftentimes by night, he can be the watcher over the weary pains of the crippled sufferers.

Month after month rolls on; the patients recover; he hires the adjoining house to his own, and converts it into an hospital ; the philanthropist's heart is light; but 10! his purse is very empty, and a heavy gloom hangs over the faces of the elder members of his family, to see how his hard-earned savings are frittered away in the support of the poor, half-famished children for whom he voluntarily provides this refuge.

Time gets on, and the rumours of cures and great alleviations are noised abroad, and slowly the public come forward in aid of an undertaking undoubtedly meritorious; but alas! it is not until the shaft of sickness and decay is implanted in the victim's bosom, and slowly, as a brighter light is beginning to dawn upon his undertaking, he dies a martyr to his zeal in the work of charity - happy, however, and intent only on the prospect of his arling plan being brought to perfection.

Again, Sir, I ask your reviewer, should such a man-provided 
such an one could be found-be considered as meriting the title of "founder" of an institution? Clearly he can but answer "yes;" and though he may do so very feebly, anticipating what is to follow, still his words are sufficiently audible for me to catch at, and quite distinct enough to make me tell him with pride, that the ideal character $I$ have attempted to portray is based upon the history of the last few years of my father's life. Such a man as the supposed character was, so was my father.

I trust, then, that I need not add any further remarks in refutation of this charge, as $I$ can but feel that the defence is conclusive. Still, before quitting the subject, I would just refer your reviewer to an article in the Morning Post of May 22nd, 1851, where the whole truth relative to the foundation of the hospital, to which $I$ am now one of the surgeons, is stated in very plain and unmistakable language; and add only that I cannot be responsible for what is stated to the contrary, either in the reports of the charity or other publications, but that the fact is as I have stated it-namely, that my father was the founder of the hospital, and that he was most enthusiastically, most energetically, and most benevolently seconded in that undertaking by perhaps the most humane and charitable individual that ever graced society with her presence-namely, Mrs. Henry Ogle, of East Bourne. Let your critic rest assured that, should my work attain to a second edition-which, despite his efforts to the contrary, it most assuredly will do-that I shall then, more strongly than ever, claim for my deceased father an honour to which, in all justice and in all equity, he was most indisputably entitled.

Thus much, then, for the first falsehood of which I have been accused by your reviewer. I will now proceed to his second charge.

As I stated at the ontset, it is not my intention to notice anything that has been urged against the actual matter of the work itself, because I have no power or right to appeal against injustice there. I cannot pass over one sentence that occurs in the review, however, without remark, because it appears to me to offer some explanation of the reason why your critic has formed so unfavourable an opinion of my work. The sentence I refer to is the following, where, after abusing my judgment somewhat unceremoniously, he says, "In this, however, we may be deceived." The next charge brought against me is that wherein I am accused of having attributed to my father the invention of the prone couch, and the introduction into practice of the prone position-an opinion evidently very much at variance with your reviewer's idea on the subject, but none the less correct, however, on that account; for I am prepared to show that the priority of the invention did, beyond all power of doubt, belong to him.

First, then, let me indignantly repel your critic's accusation of my having "ante-dated" my late father's invention, by bidding him go read my father's paper, to which he alludes, more attentively, when he will find that it is he who is in error respecting dates, not myself, as the following brief quotations from the paper in question will show:- "And in November, 1823, he was accidentally placed under my care;" and again, "From that day, which was the 2 nd of December, 1823."

At least, then, on this point your critic must stand convicted of error; for by his own showing Mr. Bampfield's essay was not delivered to the Medical Society of London until Christmas, 1823 , some months subsequent to the date that my father was employing the prone "couch," and consequently the prone "position," in the case alluded to in his paper, read before the Westminster Medical Society.

With an expression of regret that I should have been placed under the disagreeable necessity of refuting thus strongly certain statements that have been alleged against myself, and a repetition of my hope, that I may be favoured by the insertion of this letter in your widely-circulating journal,

I have the honour to be, Sir,

Your most obedient servant,

December, 1851 .

Charles Verrat.

** We publish this letter at the request of Mr. Verral; but inasmuch as the reviewer must be heard in reply, we should suspect that Mr. Verral will regret ever having written it. With respect to the error in date which Mr. Verral, in the last paragraph but two, imputes to the reviewer, we can positively vouch for the accuracy of the quotation in our last journal-namely, that the date of the invention of the prove couch specified in Dr. Verral's paper is November, 1825, and not 1823, as stated by Mr. Verral; for we have ourselves carefully examined the quotation with two copies of Dr. Verral's paper, in each of which the date is November, 1825.-ED. L.

\section{GRIEVANCES OF POOR-LAW MEDICAL OHFICERS. \\ To the Editor of The LANCET.}

SIR,-I trust you will permit me to draw the attention of my brother medical officers under the poor-law, to the propriety of petitioning parliament singly, for an inquiry into the administration of medical relief to the poor. If every medical officer were to write a short petition to the House of Commons, praying for redress of such grievances as press most heavily, and asking for some adequate remuneration for the large supplies and onerous duties which devolve upon him, I am of opinion that it would be attended with the most beneficial results. It must be quite clear, to every observant man, that any amelioration of our present condition, any grant of a meed of justice, must come from Parliament itself. It would be waste of time to trouble the Poorlaw Board further; but let an impression be made on Parliament from without, boldly, energetically, and without delay. This is the only feasible plan for us to adopt. Two thousand separate petitions sent into the House of Commons by illtreated medical practitioners, will surely lead to some search. ing inquiry, and may probably urge the House to discuss and adopt improved measures for the medical relief of the poor. If poor-law medical officers have only energy enough to aid in carrying out this plan for drawing the attention of the House to the grievances under which they labour, we may expect a modicum of relief; but if they should still remain in hopeless lethargy, so will the Poor-law Board, and so will Parliament. Let me ask you then to be united; let me ask you to use your individual energies in trying to obtain justice; not only for yourselves, bat for the poor patients who may fall to your lot. Let Parliament be shown that, as matters exist at present, the great burden of medical relief to the poor is mainly and meanly cast on your shoulders, and that it is impossible for you to discharge your duty to the sick poor without being yourselves sufferers. Let me urge you again most strenuously not to look listlessly on, while a few struggle in any movement of this kind, but join in it at once, heart and soul, and never let your efforts cease until your object be obtained.

\section{"Optima quæque dies miseris mortalibus ævi \\ Prima fugit : subeunt morbi, tristisque senectus
Et labor, et duræ rapit inclementia mortis."}

Let your motto, then, now be,-

$$
\text { "Nec mora, nec requies." }
$$

The church knows how to take care of herself, the law knows how to provide for and protect her scions, but practitioners of medicine and surgery are unrepresented, unrecognised, and miserably remunerated in their official capacity, though their services to the state and the people are unlimited. This melancholy state of things is partly owing to our own dissensions, to our disunion, and our culpable apathy. Let the time lost be now perseveringly redeemed, and let the hardly-worked, ill-remunerated practitioners of medicine unitedly ask Parliament for a just recognition of their services.

In accordance $\mathrm{with}$ the preceding views I would, therefore, humbly suggest that every medical officer under the poor-law should transcribe a short petition to the House of Commons, in terms similar to the following, modified, however, in any way which the writer may think necessary or expedient.

\section{To the Honourable the Commons of Great Britain and Ireland} in Parliament assembled.

The humble petition of , Member of the Royal College of Surgeons of England, Licentiate of the Apothecaries' Company, and a Medical Officer under the Poor-Law,

Sношетп,-That your petitioner is a medical practitioner residing in the town of , and also holds an appointment under the poor-law as medical officer for the district, in the Union. This district contains an area of acres, and a population of souls.

It is the duty of your petitioner to attend the sick paupers in his district on receipt of an order from the relieving officer, to supply them with all necessary medicines, surgical appliances, and leeches. Your petitioner has received on an average during the last three years orders, besides having numerous cases of long-continued sickness, for which a permanent medical relief card is issued, entitling the patient to attendance and medicines whenever necessary. That for the performance of this duty your petitioner is paid by the 